\title{
A STUDY OF PROLIFERATIVE ACTIVITY OF THE UTERINE EPITHELIUM OF THE PREGNANT RAT IN RELATION TO THE MORPHOGENESIS OF THE 'NEW' LUMEN
}

\author{
SANDRA PEEL AND D. BULMER \\ Human Morphology, Faculty of Medicine, \\ University of Southampton, Southampton SO9 3 TU
}

(Received 29th Fuly 1974)

In the rat, implantation occurs along the antimesometrial aspect of the uterus about Day 6 of pregnancy. Although the original uterine lumen is occluded by the decidual reaction in the region of the conceptus, it remains patent in the areas between conceptuses As the chorioallantoic placenta forms towards the mesometrial aspect, a new lumen extends around the antimesometrial aspect of the implantation (Text-fig. 1), and from about Day 12 it connects the interconceptual lumina from either side. Some of the proliferative characteristics involved in the morphogenesis of the 'new' uterine lumen are examined here.

The Wistar rats used were primigravidae, aged 3 to 6 months, and Day 0 of pregnancy was defined as the day on which spermatozoa were seen in the vaginal smear. The rats were given tritiated thymidine ( $1 \mu \mathrm{Ci} / \mathrm{g}$ body wt, sp. act. $5 \mathrm{Ci} / \mathrm{mmol}$ : Radiochemical Centre, Amersham, England) intraperitoneally or intravenously on Days $9,11,12,13,14,15,16$ or 18 of pregnancy and were killed $1 \mathrm{hr}$ later. Usually, at least three conceptuses were examined at each stage of pregnancy but they were not necessarily from the same animal. Tissues were fixed in buffered formol saline or Carnoys fixative. Autoradiographs were prepared using Ilford K5 emulsion and Kodak D19 developer.

The percentage of labelled cells in transverse sections of the uterus was determined for each of three categories of the uterine epithelium. For the first category, approximately 200 glandular epithelial cells were counted regardless of whether the glands were in regions of or between conceptuses; for the second, epithelial cells lining the whole luminal surface of a section of uterus between conceptuses were counted; for the third, a count was made of all epithelial cells which lined the outer aspect of the 'new' lumen as it extended around the conceptus. The number of cells in the third category varied from 50 (in a section of the furthermost extension at Day 9) to about 4000 at Day 18. The epithelial cells covering the antimesometrial decidua had an atypical appearance and have been described elsewhere (Bulmer \& Peel, 1974).

Table 1 shows that very few glandular epithelial cells were labelled at each stage examined. In contrast, the percentage of labelled surface epithelial cells in interconceptual areas between Days 9 and 13 was between 10 and $20 \%$. 


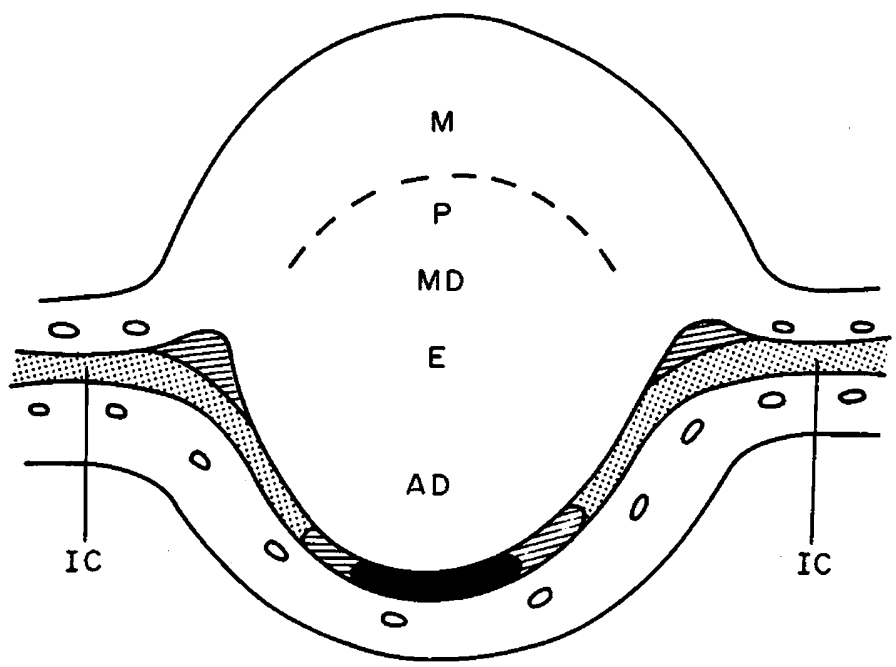

Text-FIg. 1. Diagrammatic representation of a longitudinal section through part of a pregnant rat uterus illustrating the progressive extension of the uterine lumen from its position at Day 9 (stippled), and its position at Day 11 (hatched) to its position about Day 12 (solid) when continuity between the interconceptual lumina (IC) is re-established. Uterine glands are represented by small ovals; $M$ indicates the mesometrial region; $M D$ is the site at which the chorioallantoic placenta develops; $\mathbf{P}$ and $A D$ are the mesometrial and antimesometrial decidua respectively; and $\mathrm{E}$ is the region occupied by the embryo.

Table 1. The percentage of rat uterine epithelial cells labelled with $\left[{ }^{3} \mathrm{H}\right]$ thymidine between Days 9 and 18 of pregnancy

\begin{tabular}{|c|c|c|c|c|c|c|c|c|}
\hline $\begin{array}{l}\text { Uterine epithelial } \\
\text { cell type }\end{array}$ & 9 & 11 & 12 & $\begin{array}{l}\text { Days of } p \\
13\end{array}$ & $\begin{array}{r}\text { ancy } \\
14\end{array}$ & 15 & 16 & 18 \\
\hline $\begin{array}{l}\text { Glandular } \\
\text { epithelial cells }\end{array}$ & $\begin{array}{l}0 \\
0 \\
0 \cdot 6\end{array}$ & $\begin{array}{l}0 \\
0 \\
0\end{array}$ & $\begin{array}{l}0 \\
0 \cdot 8 \\
0\end{array}$ & $\begin{array}{l}0 \\
0 \\
0\end{array}$ & - & $\begin{array}{l}0 \\
0 \\
0\end{array}$ & $\begin{array}{l}0 \\
0 \\
0\end{array}$ & - \\
\hline $\begin{array}{l}\text { Surface cells of } \\
\text { interconceptual lumen }\end{array}$ & $\begin{array}{r}13 \cdot 8 \\
17 \cdot 6 \\
9 \cdot 9\end{array}$ & - & $\begin{array}{l}17 \cdot 6 \\
18 \cdot 7 \\
16 \cdot 9\end{array}$ & $\begin{array}{l}12 \cdot 7 \\
15 \cdot 0\end{array}$ & - & $\begin{array}{l}1.5 \\
1.9\end{array}$ & $\begin{array}{l}0 \\
1.4\end{array}$ & - \\
\hline $\begin{array}{l}\text { Outer surface } \\
\text { cells of lumen } \\
\text { extending around conceptus }\end{array}$ & $\begin{array}{l}* 3 \cdot 7 \\
\text { to } \\
39 \cdot 5\end{array}$ & $\begin{array}{l}30 \cdot 4 \\
52 \cdot 7 \\
45 \cdot 5\end{array}$ & $\begin{array}{l}43 \cdot 5 \\
61 \cdot 0 \\
33 \cdot 2\end{array}$ & $\begin{array}{l}61 \cdot 4 \\
61 \cdot 5 \\
61 \cdot 6\end{array}$ & $\begin{array}{l}8 \cdot 7 \\
5 \cdot 6 \\
7 \cdot 7\end{array}$ & $\begin{array}{l}2.1 \\
0.5 \\
0.6\end{array}$ & $\begin{array}{l}1 \cdot 7 \\
0 \cdot 4 \\
0 \cdot 2\end{array}$ & $\begin{array}{l}0.6 \\
0.2 \\
0.5\end{array}$ \\
\hline
\end{tabular}

Each value is from one conceptus except for the figure shown by an asterisk for which a range of values was observed and has been analysed in Table 2 and Text-fig. 2 .

Proliferative activity was even higher in epithelial cells related to the conceptus, 30 to $60 \%$ of the cell being labelled between Days 11 and 13. After Day 13, there was a reduction in the proliferative activity and from Day 15, fewer than $2 \%$ of the cells were labelled.

Not only did the labelling index of the epithelium vary with the stage of pregnancy but wide variations were seen at the same stage of pregnancy. At Day 9, the labelling indices in sections which showed the extensions of the 
new lumen varied between 3.7 and $39.5 \%$. This variation was partly due to differences between animals or between implantations. Variation also occurred in different areas of a single conceptus and this aspect was studied further in serial transverse sections of a 9-day specimen in which the labelling index varied from 3.7 to $20.6 \%$. The results are shown in Text-fig. 2 in which some

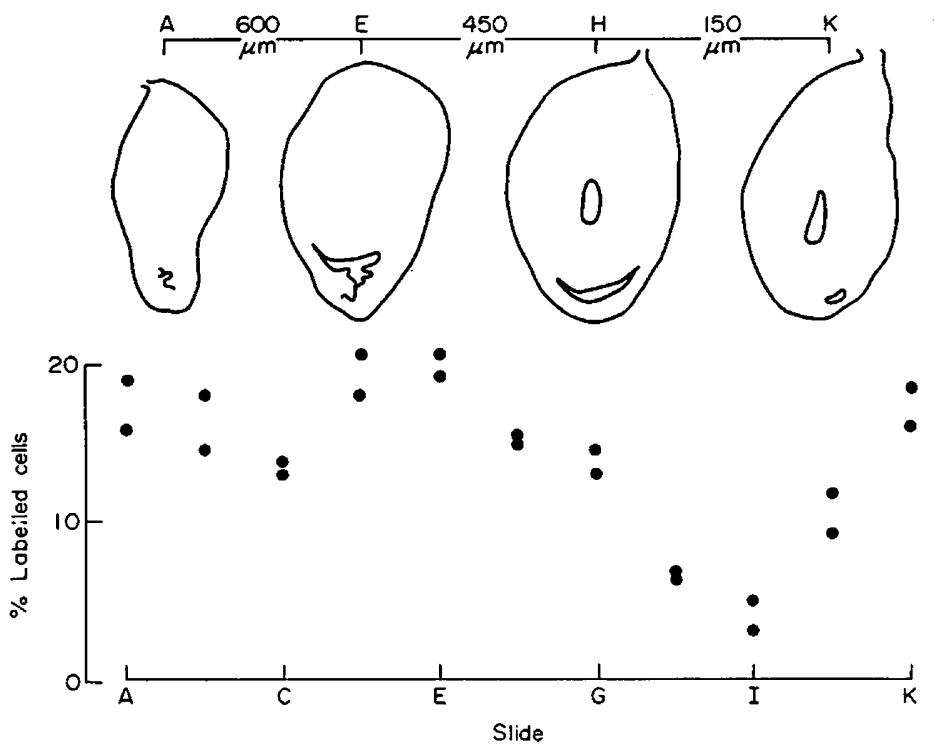

Text-Fig. 2. The percentage of uterine epithelial cells labelled with $\left[{ }^{3} \mathrm{H}\right]$ thymidine is shown for two (non-adjacent) sections on eleven slides (A to $\mathrm{K}$ ) taken from a set of serial transverse sections of a rat conceptus at Day 9 of pregnancy. The outline topography of a section from each of slides $\mathrm{A}, \mathrm{E}, \mathrm{H}$ and $\mathrm{K}$ is shown and their features are described in the text; the approximate distance between the sections is indicated.

of the serial sections are illustrated diagrammatically. In Slide A, the uterine lumen was almost interconceptual; in Slide E, there were lateral extensions of the lumen around the decidua; in Slide $\mathrm{H}$, the embryonic sac was separated from the uterine lumen by antimesometrial decidua, and in Slide $\mathrm{K}$, the most advanced extension of the new lumen occurred.

The observations in Text-fig. 2 were analysed by Duncan's multiple range test. Transformed percentages were used and the results of the analysis are shown in Table 2. The labelling indices of the uterine epithelium on Slides $\mathrm{H}$

Table 2. Analysis by Duncan's multiple range test, using transformed percentages, of the labelled epithelial cells in sections from a series through the 9-day pregnant rat uterus

\begin{tabular}{l|cccccccccccc}
\hline & $E$ & $D$ & $A$ & $K$ & $B$ & $F$ & $G$ & $C$ & $\mathcal{1}$ & $H$ & $I$ \\
\hline $\begin{array}{l}\text { Trans- } \\
\text { formed } \% \\
\begin{array}{l}\text { labelled } \\
\text { cells }\end{array}\end{array}$ & $26 \cdot 5^{\mathrm{a}}$ & $26 \cdot 0^{\mathrm{a}}$ & $24 \cdot 6^{\mathrm{ab}}$ & $24 \cdot 5^{\mathrm{ab}}$ & $23 \cdot 8^{\mathrm{ab}}$ & $22 \cdot 9^{\mathrm{ab}}$ & $21 \cdot 8^{\mathrm{bc}}$ & $21 \cdot 7^{\mathrm{bc}}$ & $18 \cdot 8^{\mathrm{c}}$ & $14 \cdot 6^{\mathrm{d}}$ & $12 \cdot 0^{\mathrm{d}}$ \\
\hline
\end{tabular}

Any two figures with different superscripts are significantly different $(P<0 \cdot 1 \%)$. 
and I were significantly lower than those on all other slides analysed $(P<$ $0.1 \%)$, and the labelling indices on Slide $\mathrm{K}$ were significantly higher $(P<$ $0.1 \%$ ) than those on Slide J. The leading edge of the extending lumen with a labelling index between 15 and $20 \%$ was separated from a region with a similar labelling index by a region of significantly lower labelling.

Little attention has been paid to the proliferation of the uterine epithelium during gestation. Finn \& Martin (1967) and Martin \& Finn (1971) recorded a higher mitotic index in glandular than in luminal epithelium on Day 3 of pregnancy in the mouse though by Day 5 there were virtually no mitoses in either epithelium in inter-implantation sites. The results of Epifanova (1971) and those in Table 1 also emphasize that glandular and luminal epithelia do not form a uniform population.

The highest proportion of cells synthesizing DNA occurred in the new lumen about Days 12 to 13. Until recently, the highest labelling index reported for uterine epithelium was less than $30 \%$ (Epifanova, 1971). Martin, Finn \& Trinder (1973) reported a labelling index of 70 to $80 \%$ in castrated mice given oestrogens but suggested that this was a highly synchronized rather than a steady state population. Although the high labelling indices observed in the new uterine epithelium at Days 11,12 and 13 may represent synchronous waves of proliferation, it seems more likely that the majority of these cells are in cycle and that a high proportion of their cycle time is spent in DNA synthesis.

In the regions between conceptuses, the labelling indices were not as high as those recorded for the extending lumen but there was a reduction in proliferative activity in both areas between Days 13 and 15. The reason for this is not clear. It may be that an adequate new lumen has been established and the associated cell proliferation therefore ceases. It may be partly due to an altered hormonal environment affecting the proliferative characteristics of the uterine epithelial cells but it is difficult to relate the time sequence of this change in labelling index to precise alterations in hormonal environment because of the complexity of the endocrinological changes during pregnancy (Deanesly, 1966; Wotiz, Scublinsky \& Walker, 1972; Pepe \& Rothchild, 1973).

The reason for the regional variation in labelling index in the epithelium of the extending lumen at Day 9 is obscure. The endocrine environment might be expected to have a uniform effect and it is evident that other factors as well as maternal and placental hormones are involved in controlling the proliferative activity associated with the formation of the new lumen.

We are grateful to Dr P. Cook for carrying out the statistical analysis.

\section{REFERENCES}

Bulmer, D. \& Peex, S. (1974) An autoradiographic study of cellular proliferation in the uterus and placenta of the pregnant rat. F. Anat. 117, 433-441.

DeanesLy, R. (1966) The endocrinology of pregnancy and foetal life. In Marshall's Physiology of Reproduction, 3rd edn, Vol. III, pp. 891-1063. Ed. A. S. Parkes. Longmans, London.

Epifanova, O. I. (1971) Effects of hormones on the cell cycle. In The Cell Cycle and Cancer, pp. 145-190. Ed. R. Baserga. Marcel Dekker, New York.

Finn, C. A. \& MARTIN, L. (1967) Patterns of cell divison in the mouse uterus during early pregnancy. 7. Endocr. 39, 593-597. 
Martin, L. \& Finn, C. A. (1971) Oestrogen-gestagen interactions on mitosis in target tissues. In Basic Actions of Sex Steroids on Target Organs, pp. 172-188. Eds. P. O. Hubinot, F. Leroy and P. Galand. Karger Basel.

Martin, L., Finn, C. A. \& Trinder, G. (1973) Hypertrophy and hyperplasia in the mouse uterus after oestrogen treatment: an autoradiographic study. $\mathcal{F}$. Endocr. 56, 133-144.

Pepe, G. J. \& RothchiLd, I. (1973) Serum progesterone levels in ovariectomized rats injected with progesterone and estrone: relation to pregnancy maintenance and growth of decidual tissue. Endocrinology, 93, 1193-1199.

Wotiz, H. H., Scublinsky, A. \& WALKER, C. (1972) Effect of oestrogen antibodies on pregnancy in the rat. Gynec. Invest. 3, 124-125. 